\title{
From Communist Fan Clubs to Professional Hooligans: A History of Polish Fandom as a Social Process
}

\author{
Radoslaw Kossakowski \\ University of Gdańsk
}

\begin{abstract}
The main aim of this article is to present the history of Polish football fandom as a social process which has coincided with the processes of transformation of Polish society over the last few decades. The fan movement in Poland dates back to the early 1970s when the communist authorities attempted to channel the activity of supporters. The 1980s, however, brought the development of a spontaneous movement with strong accents of hooliganism. The post-1989 transformation led to an economic and social crisis, with the rule of anarchy in football stadiums. Along with the formation of the democratic order, the fan movement evolved into different sections focused on particular aspects of activity. The paper is also devoted to the ideological dimension of fan culture, related to the conflict with the government at the turn of the 2010s.
\end{abstract}

Le but principal de cet article est de présenter l'histoire du supportérisme dans le football polonais comme un processus social qui a coïncidé avec les processus de transformation de la société polonaise durant les quelques dernières décennies. Le mouvement des supporters en Pologne remonte au début des années 1970, quand les autorités communistes tentèrent de canaliser leurs activités. Les années 1980 ont cependant vu se développer un mouvement spontané avec de forts accents de hooliganisme. La transformation post 1989 a mené à une crise économique et sociale en érigeant l'anarchie comme loi dans les stades de football. Avec le développement de l'ordre démocratique, le mouvement supportériste a évolué en différents groupes se focalisant sur des aspects spécifiques de l'activité. Ce papier s'intéresse également à la dimension idéologique de la culture des supporters en lien avec le conflit, apparu au début des années 2010, avec le gouvernement.

Cultural changes influence various domains of social life, including sport. For example, the process of commercialization and neoliberalization in football impacts on transformation of fan communities (Dubai 2010; King 1998; Giulianotti 2011), which manifests itself in resistance and social action (Fitzpatrick 2013). Other factors at play involve political, ideological and even religious determinants (May 2015). Consequently, it is important to study the relationship between, for example, national identity and fan culture (Gibbons 2014). The impact of external factors on fandom has important consequences in terms of 'reflexivity' of this culture (Numerato 2015) and creating identity politics in a new way. Reaction to external sociocultural processes should not be separated from the social process of redefining the identity of fan groups. For example, the 'Against Modern Football' movement (Webber 2015) is not particularly relevant in Poland as the process of 'modernization' of football is at a different stage of development than in other countries (e.g., England) and does not result in radical changes of traditional fan communities. In Poland, there are differ-

The author is with the Department of Social Sciences, University of Gdańsk, Gdańsk, Poland. Address author correspondence to Radoslaw Kossakowski at radoslaw.kossakowski@ug.edu.pl. ent social processes at work, shaping the development of Polish fandom (Kossakowski 2015).

The main aim of this article is to present the history of Polish football fandom as a social process which in an unplanned and undirected way has coincided with the processes of transformation of Polish society over the last few decades. It is assumed that some aspects of this social process involve 'civilization' in terms of regulating behavior (e.g., an informal hooligan code) and developing normative and institutional structures. As a result of tensions between internal fan norms and external imperatives of the system (law, politics), fan circles have evolved from an amorphous phenomenon into a well-functioning social/civic movement. At the same time, however, violent and negative elements continue to exist within its structure. The transformation of fandom would have been impossible without the processes of modernization of the state, the collapse of communism and the development of a democratic political system and civic society. The analysis makes use of Norbert Elias's concept of 'processual' sociology. He underlined that transformation of individuals goes hand in hand with the development of the state as the structure to control violence. With the development of social structures and the evolution of economic life, individuals confront the necessity of dealing with progressive 'functional differentiation', as well as reflexivity of attitudes and behavior 
(Elias 2012). The habitus of fans is also the result of historical changes. It seems that it is right to say that the moods in the stands to some extent reflect the sentiments of the public (Guschwan 2007).

The article begins with a presentation of the key assumptions of Elias's concept of social process. The next paragraphs focus on the history of Polish fandom since the 1970s, when the communist authorities attempted to channel the activity of supporters. The 1980s, however, brought the development of a spontaneous grass-roots fan movement with strong accents of hooliganism. The post-1989 transformation led to a deep economic and social crisis, with the rule of anarchy and violence in football stadiums. At the turn of the century, along with the formation of the democratic order, the fan movement evolved into different sections focused on particular aspects of activity. In other words, fan communities developed a structure conducive to their operation in the environment of the emerging civil society. Fan culture also has its dark side (violence, vandalism), which proves that it is vulnerable to the 'decivilizing' pressures (Mennell, Goudsblom 1998: 20). The final part of the paper is devoted to the origins of the ideological dimension of fan culture, related to the conflict with the government at the turn of the 2010s.

\section{Methods}

The following analysis is based on qualitative research: (1) in-depth semistructured interviews conducted with fans participating in historical events (in the 1970s, 1980s, etc.), as well as with those who develop the movement today; (2) content analysis of documents, newspaper and magazine materials, fan websites, and books. Among the informants there were also people who are not associated with fan circles. As a result, it was possible to discover various interpretations of the phenomena under consideration. Quotations from interviews are marked as follows: [Club_supporter], [City_occupation] (in the case of respondents who do not belong to the fan movement). The study involved 52 interviews (43 male and 9 female informants) conducted between 2014 and 2016.

The fans were supporters the following football clubs: Lechia Gdańsk, Arka Gdynia, Lech Poznań, Legia Warsaw, Śląsk Wrocław, Miedź Legnica, ŁKS Łódź, Widzew Łódź, Górnik Zabrze and GKS Tychy. The clubs in question represent a broad spectrum (from the most successful and renowned to those recognized only at the local level) and a different fan base (while in the case of e.g., Legia or Lech it is very large, such clubs as GKS Tychy have a more limited fan base). The recruitment of fans involved the use of the snowball sampling method. In view of the hermetic nature of the fan world, it was crucial to gain an appropriate level of trust, thanks to which one respondent recommended another.

It is worth noting that the respondents might idealize issues relating to hooligan activity, which is difficult to verify since the author has no access to this domain. One should be particularly sensitive to the discourse of 'honor' that involves respecting the rules (the only possibility to verify this discourse was to confront it with the respondents' 'opponents' and follow their discussions on Internet forums, which - in some cases-made it possible to form a more objective evaluation). The hooligan world in Poland is characterized by a continuous struggle for 'authenticity' and monopolization of high esteem. It resembles the construction of reputation described in ethnographic research on hooligans (Pearson 2015).

\section{Norbert Elias and Social Process}

Elias perceives society as 'the processes and structures of interweaving, the figurations formed by the actions of interdependent people' (1978: 103). In social duration, individuals and groups are interwoven, and activities are transformed into social processes which are neither intentional nor intended (Elias 1987). These processes are characterized by 'relative autonomy' (Elias 2009a: 7): they take place despite the actions of individuals, but - on the other hand-are not independent of people. Although unplanned, the social process is driving with a 'constancy of direction' (there). The direction of the process, not designated by any demiurge, is characterized by increasing mutual dependency and functional differentiation.

For example, over time football has changed its nature from a violent game with practically no rules to a 'civilized' form of competition and entertainment, where incidents of gratuitous violence are quite rare (Elias 2009c). The process of 'futbolization' can be interpreted by using such terms as function, structurizing, regulations, socialization, etc. '(. . . ) The continuity of a process is mediated by the transmission of society-specific knowledge, acquired by learning, in the form of social symbols. (... ) selection through elimination contests is determined (. . . ) by innovation of knowledge" (Elias 2009b: 8). Socially established knowledge is essential to adequately involve various figurations in the historical process, especially when the network of interdependence is so complex that it becomes impossible to act only by intuition.

Norbert Elias observes that 'the concept of "social process" relates to continuous long-term transformations' (2009a: 4) and it is worth pointing out that a social process can involve both 'growth' and 'decline'. One should not naively believe that social processes always evolve from a less desirable state toward a higher stage of development (whatever the meaning of 'higher'). This makes it easier to explain the periods of lawlessness, wars, cruelty or 'moral decadence' in the history of human societies. Elias analyses also the 'decivilizing spurts' (involving brutal conduct and violence), and in his book The Germans (1996) he discusses the possibility of a state-induced 'deficient' process of civilization. Certainly it is necessary to consider the fact that the civilizing process is dialectically accompanied by phenomena that constitute its 'dark side'. 
The social process is bipolar and reversible. Each evolution can be 'stopped', 'reversed' or converted in a nonlinear manner. Elias concludes that 'the principal forces driving social processes include tensions and conflicts in connection with the monopolisation' (2009b: $6)$. The fan movement can serve as an example of these observations. Conflicts within the fan circles are one of the key forces 'stretching' and reconstructing the world of fans. Domination over the opponent is achieved by means of a tendency to monopolize the fan figuration. Until a few years ago, there was a popular ranking of hooligan crews, the so-called 'Hooligan League' (with scores published in underground zines). These were mainly groups of supporters from the largest clubs; for obvious reasons, they had more members and could select the strongest fighters. The ranking ceased to be relevant in recent years following a decrease in the number of hooligan fights. As a result of police invigilation, hooligans are not keen on public interest or esteem. Today, the standing of particular crews depends on the results of infrequent incidents involving physical confrontation and opinions posted on Internet forums.

Norbert Elias identifies other characteristics of longterm, complex social processes: functional differentiation (whereby the development of social system leads to the emergence of different units characterized by particular normative imperatives and functions, e.g., the legal system, educational system, religion, sport, work environment separated from households, etc.; they come as a response to the increasing complexity of social environment), social integration, state-formation processes and another long-term (also unplanned) trend-the change in standards of social behavior, i.e., 'in what is socially permitted, what is commanded and forbidden, and the corresponding change in social personality structures in the direction of an increasing civilization of human feelings and behavior' (Elias 2009b: 32). The transformation of the state and a growing social awareness have gone together with the historical transformations of the fans' figuration, a phenomenon accompanied by an unprecedented 'functional differentiation' - a division of the fan movement into 'specializations'. It is important, then, to provide a historical and cultural analysis to make the 'social process' of fandom more understandable.

Figurational theory has become the subject of criticism and dispute at the ontological, epistemological and explanatory level (Layder 1986). It is certainly not the most perfect frame of analysis, and the decision to implement it has been, as always, arbitrary. At the same time, however, it allows to illustrate some processes embedded in a particular cultural context. Despite its European origins (Elias analyzed empirical examples mostly from Germany, France and England), this approach has been implemented - in an interesting way — also, for example, in the analysis of American society (Mennell 2007) and in sports sociology (Elias and Dunning 1986; Malcolm 2012). The present analysis is based on the assumption that while figurational approach can provide a valuable frame of evaluation of the process of transformation of
Polish fandom (against the background of changes in Polish society), it certainly does not exhaust all possible interpretations (e.g., it is not appreciated in terms of predicting future trends, see Bauman 1990). This article opens rather than concludes the discussion concerning both the Polish context and the explanatory potential of Elias's ideas.

\section{Communist Fan Clubs and 'Solidarity' in the Stands}

The fan movement in Poland dates back to the early 1970s, when fans of a number of clubs (ŁKS Łódź, Polonia Bytom, Legia Warsaw) organized support for their teams. At the time, Polish stadiums were visited by clubs taking part in European Cup games (such as Feyenoord Rotterdam and Saint-Étienne) and the behavior of their supporters provided inspiration for Polish fans. Although they tried to imitate Western examples, it was local animosities that were to function as the main factor behind the formation of 'firms' supporting Polish football clubs. They were first started to protect their 'own area' against the 'strangers', i.e., supporters of clubs from other cities. Animosities were further fueled by the fact that clubs were affiliated with official state institutions (e.g., Legia was an army club, and Wisła Cracow was a club of the Citizens' Militia (MO), the communist police).

Communist authorities tried to channel the movement by setting up official fan clubs which received state sponsorship for their activity, including organization of social events and trips to away matches. According to the logic of the communist regimen, the authorities tried to make fandom a 'planned' process, as was the case of centrally planned economy ${ }^{1}$. This policy involved the establishment of nationwide 'fan clubs' organizing regular meetings of representatives of their local branches. Their activity was supervised by communist party activists. However, the real fan movement was a grass-roots initiative in opposition to the political system of the day. Toward the end of the 1970s, informal groups of football fans were active in nearly thirty clubs (Goksiński 2014: 389). Figurations of fans were formed by young people (students) and workers. Although they did not differ from the rest of society, as a group they tried to behave spontaneously, or at least made an effort to resist ideological 'exploitation' pursued by the authorities.

The communist party monopolized all aspects of life, but the state monopoly was not the result of a natural process of historical tensions and competition as in the civilizing process described by Elias. The mechanism of centralization served the "concentration of all social resources for the implementation of both the target goals of the system and its subtargets. For these reasons, the system has not only a centralist, but also hierarchical nature. Organizational units located at the lower levels of the organizational structure are subordinated to a higher level' (Tarkowski 1994: 218). The country was 'integrated' by closing the borders and restricting opportunities to discover other cultures and 
values. There was no development of civic attitudes (except for the underground structures of anticommunist opposition), or a sense of community which would not be imposed by coercion. Indeed, communism stimulated the development of 'homo Sovieticus' mentality (Tischner 1992) based on a conformist attitude, lack of individual initiative, and dependence on the system. Although in the 1970s the fan movement began to take an organizational form, it was not a coherent cultural formation. Hence, it is difficult to talk about a committed 'social identity' of the fan.

The 1980s were a period of decline of the communist state. The beginning of the decade saw a social revolution leading to the emergence of the Solidarity movement. At the same time, the results of opinion polls showed that Polish society was aware of the pathological nature of the system, e.g., overgrown bureaucracy, bribery, cronyism, poor organization of work, and excessive influence of the communist party on the economy (Koralewicz, Ziółkowski 1990). The inefficiency of the system was manifested in rampant inflation, reaching a level exceeding $70 \%$ in 1988 . The system which was supposed to bring prosperity in fact led the state to the economic collapse and 'unplanned' system transformation: 'instead of talking about crisis, we should rather talk about a state of permanent backwardness' (Tarkowski 1994: 205).

In the 1980s, news of the activity of English 'hooligans' reached Poland and the level of football-related violence increased. Owing to the official 'success propaganda', the scale of the phenomenon was never publically acknowledged. For example, as unofficially reported, in the riots during the 1980 Polish Cup final between Legia Warsaw and Lech Poznań there was at least one dead and several hundred injured. On the other hand, the same period saw the stands become a scene of anticommunist activity. Slogans such as 'Solidarity' (Solidarność) and 'Down with the commies' (Precz z komuna) were often to be heard in Lechia Gdańsk stadium (Wąsowicz 2006). Rioting against the authorities and fights with the police have remained a distinctive feature of Polish fans ever since. Official 'fan clubs' organized by the authorities perished, and fans organized themselves in their own way, which was usually manifested in mass trips to away matches. Taken on regular trains, the trips were spontaneous and involved binge drinking and fights with opposing fans. Law enforcement officers acted reactively, there was no special law regulating football matches. The most common 'strategy' of the Citizens' Militia (the communist police) was to punish the most hot-headed supporters by beating them and to release them home. The chaos of the fall of the state system was matched by the lack of any serious structures of the fan movement.

\section{System Transformation and the 'Decivilizing Process' of Fandom}

The fall of the sociopolitical system resulted in a phenomenon described by sociologists as a 'social vacuum' (Nowak 1981). The term refers to the situation in which there is a gaping hole-there are no civic communities, associations and grass-roots initiatives-between the level of abstractly perceived nation, and the level of individuals focused on family life. The elements of social fabric enhancing the development of functional differentiation in the space of community and citizenship did not form. At the level of the system, institutional instruments of terror and coercion-at least theoretically_tamed 'uncivilized' behavior of individuals, while ideological censorship blocked the possibility of manifestation of alternative ways of thinking to 'integrate' people in the communist spirit. The first period of political transformation (1989) saw the new democratically elected authorities, without stable structures, having to face the necessity of suppressing enormous inflation, high unemployment ${ }^{2}$ and supporting the collapsing economy, which was not able to compete in a free market environment. Political turbulence (in 1989-1997 Poland had eight prime ministers) did not help to resolve the economic problems.

Apart from these problems, there was also anachronistic law and disputes about the impact of the old communist apparatus on public life. All this meant that the football figuration was left to itself. Consequently, the first years of the democratic system in the discipline were characterized by large-scale disintegration, nepotism and corruption. The culmination of the pathological situation in Polish football came with a corruption scandal involving more than fifty clubs and resulting in charges against about six hundred people. What is important in the context of the interpretive framework used in this study is that tackling corruption required legislative changes which created the offense of bribery in sport (introduced into the Criminal Code on 1 July 2003). Thus, the development of the state apparatus and law was necessary to 'civilize' the football figuration.

The instability of the situation in the country resonated in the stadiums. Indeed, in the early years of the post-1989 transformation the culture of violence in Polish football stadiums developed on an unprecedented scale. The data indicated an increasing number of hooligan incidents: 190 cases in 1991, 220 in 1992, 440 in 1993, 584 in 1994, 906 in 1995, 917 in 1996 and 1075 in 1997 (Gorący 2009). A 'hardcore' supporter of ŁKS Łódź describes the atmosphere of those times in his two-volume diary (eR 2014, 2015). He recalls traveling across Poland in a most 'uncivilized' manner: free-riding on trains (endless conflicts with the conductors), vandalizing public property, heavy drinking (sometimes for several days), 'hunting' for supporters of opposing teams, shoplifting, conflicts with the police. A Miedź Legnica supporter recalls:

Each trip meant a scrap, literally, every trip. We travelled with the gear, wooden planks and stones. (...) the 1990s, it was like... bricks flying in the stadium, people threw just about anything. It was often a miracle that no one was killed every week. When you ripped out all those bricks from the stadium over and over again, the stadiums were already falling 
apart and there was no stuff left to fight with, just planks, bits of wood, fencing.

This phenomenon exemplifies 'decivilizing spurts' related to the fact that 'rising levels of danger and incalculability in social life quite quickly render people more susceptible to fears and fantasies' (Mennell 1996: 113). Elias comments: 'The armour of civilized conduct would crumble very rapidly if, through a change in society, the degree of insecurity that existed earlier were to break in upon us again, and if danger became as incalculable as it once was. Corresponding fears would soon burst the limits set to them today' (2012: 576). The lack of any structure organizing the life of supporters in terms of regulations involved very peculiar forms of the search for 'security':

We had some locks, some chains to lock up the train compartment, to lock one end of the carriage, the other... Oh, my God... what a time... Now, you are escorted by the police all the way. It didn't use to be like that back then, what police? [Górnik Zabrze_supporter]

A considerable proportion of the fan figuration consisted of individuals loyal to ultra-right-wing ideology; racist chants were often heard in the stadiums, and symbols of skinhead culture were a familiar sight ${ }^{3}$. The democratic structures of the state did not have any tools to react to hooligan incidents at their disposal. In the first years of the 1990s, football matches had a similar scenario: fights between fans (at railway stations, streets, around the stadiums, in the stands), sometimes leading to invading the pitch (interruption of the sporting event), followed by police intervention and escorting supporters to their stand or train (Miedź Legnica supporter: 'The rules were like this: the police beat us, we beat the police, no one went to court. Today, when the police beat us, you go to court'). It should be emphasized that in most cases the confrontation between fans was not planned or arranged. 1997 marked an important turning point: in view of the situation in the stadiums the government decided to introduce the Act on Mass Events Security (Ustawa z dnia 22 sierpnia 1997 roku o bezpieczeństwie imprez masowych).

\section{The Beginning of 'Functional Differentiation'}

'Parliamentarization' of Hooliganism. The end of the 1990s brought a slow change in the character of fan culture and marked the beginning of its 'functional differentiation'. November 1998 saw the first arranged fight planned by both 'crews' (Pol. ustawka; pl. ustawki), held between the supporters of Lechia Gdańsk and Arka Gdynia. One of the participants, an Arka fan who was sixteen at the time, recalls: 'This guy asked me if I wanted to fight. I said yes. The adrenaline made my legs shake. I had my nose broken and my face was all bruised. On the next day, everyone at school knew what I'd been up to'. Although it sounds paradoxical (the matter concerns violence against others), a shift of emphasis to arranged fights was an important motive for change in the figuration of fans. In the early 2000s, one of the fan magazines wrote: 'Nowadays, hooligans meet for the popular "ustawka", where they show their superiority over the rivals, and where there is no risk that something could happen to outsiders. Someone might say that there is a law against it. This is a fact, but I repeat once more, no outsider suffers and no property is damaged' (Artur 2002: 19).

Arranged fights became the subject of a debate in the fan circles, including such issues as their 'advantages' and 'disadvantages' (see Malkontent 2002: 11), rules and principles (which should be based on honor and respect for the opponent, 'Zgred' 2002: 31), and practical arrangements (e.g., equal number of participants, their age, a ban on dangerous objects, the so-called 'technical equipment', the site, etc.). The rules of relationship between fans began to be regulated by an informal code (e.g., the so-called 'Fan Code') $)^{4}$. In 2004, the so-called 'Poznań Pact' was signed-fans of several dozen clubs met to discuss the rules concerning not using 'equipment' in fights and the principle of 'truce' during the Polish national team matches (in 1995, before Poland vs. England match in Chorzów, a fan of Pogon Szczecin was stabbed by a fan of Cracovia Cracow). With rare exceptions, the 'Poznań Pact' has functioned ever since.

Is such 'honourable' aggression against an opponent a proof of the 'civilizing process' of fan culture? Judged from the perspective of a broader context of social conduct, violent acts would be considered 'uncivilized'. On the other hand, the historical social process shows a slow but distinct change of fan attitudes. While in the 'crazy' 1990s such issues as dangerous 'equipment' were not a subject of concern (one of the respondents recalls: 'We used everything, samurai swords, anything that was at hand; you protected yourself, because you never knew what could happen'), they are certainly considered today. Although the perspective of eliminating such extreme affect as aggression (and hate) from the fan figuration is very distant, it is crucial to recognize the changes, influenced also by 'external constraints'. Criminal and civil law developed in the process of state formation to protect the social order becomes an important factor of disciplining the fans.

In the old days, you just got a few hits with a baton from the police and they would let you go. Your father might have given you a hiding when you got back home. Today, you're charged with assaulting a police officer, that's a big thing; it's not worth it. Those guys who need more excitement, they keep quiet and they do their thing in the woods. No one jumps over the fence to run across the pitch anymore; there's too much to lose. [Arka Gdynia_supporter]

A glance at the history of Polish fandom in the last several years clearly reveals that the law has become 
more restrictive and has come to affect an increasing spectrum of behavior. In the photographs from the turn of the century it can be seen that the fans firing flares wear the same clothes as the others and do not cover their faces. They did not have to take any precautions because although pyrotechnics was illegal, the law was not enforced. Today, the ban on pyrotechnics is very strict (and carries the penalty of a prison sentence of between three months and five years), which means it is perceived as risky. Hence, the precautions, such as disguise (e.g., painters' overalls, dark glasses or masks), are hardly surprising. The development of the state-making process in its legal dimension has an impact on the specialization and functional differentiation in the fan figuration, as it induces solutions which have not been taken into account before.

Even where there is still violence (hooligan fights), there are more rules and 'regulations', which modernize and professionalize this 'deviant' aspect of supporting (the 'parliamentarization' of fighting, as Elias could say). Some of the hooligan fights become a kind of 'sports contest', a form of 'quest for excitement' (Elias, Dunning 1986). The 'Team Tournament of MMA' is a case in point: 'teams' of supporters from different clubs (e.g., Arka Gdynia, Lech Poznań, ŁKS Łódź, Zagłębie Sosnowiec) fight in a purpose-built cage, follow a set of sports rules and are controlled by a referee; medical care is provided). Does it mean that hooligan fights serve as a kind of 'catharsis' for some subculture groups? An interesting interpretation is proposed by a person who is not associated with the fan movement:

Personally, the way I see it is that from time to time, every several years or every few decades, there is a war and that's it. People need to go somewhere and release their emotions. The nation is purified. (...) And these are young people, and, well, it is good when they go to the gym and let off some steam, isn't it? Do they need yet another source of adrenaline? [Zabrze_City Council]

\section{Robert van Krieken observes as follows:}

Important as driving forces behind the civilizing process are competition, and the opportunities for advantage offered by being distinctive in the realm of manners and morals. Continuing competition between various social groups has generated both the willingness to submit to the demand of etiquette and the increasing subjection of people's bodies, emotions and desires to stringent controls and ever more demanding forms of self-discipline. Competition has also driven the spread of the civilizing process, first to the higher bourgeois strata, in their attempts to enter court society, and then in turn to the strata below them (2007: 31)

This observation is useful in the analysis of the fan figuration. Competition is the core activity of fans, especially hooligans. If competition is to be consid- ered credible, it must be based on generally accepted principles which involve both 'manners' and 'morals' (however specifically conceived). As for self-discipline, it is important that today's hooligan crews are composed of individuals who are involved in martial arts (boxing, MMA, etc.). It would not be an exaggeration to conclude that hooligan activity as it is today involves less spontaneity and randomness, and increasingly more calculation, strategy and training regimen. Many hooligans care about healthy nutrition, avoid alcohol and drugs, and work out in gyms (Śląsk Wrocław supporter: 'It's a generational thing; every generation has different priorities, I can say. For example, in the past, fans used to be spontaneous when they traveled, there was a lot of alcohol. Today, it's a kind of sport; they despise alcohol and they don't respect people who reel around'). The following comment from a fan indicates the context of values, but also notes historical changes:

I took part in ustawki [arranged fights, RK], all of them were honourable. First, Lech [Poznań, RK] counted us, then we counted Lech. When someone screamed 'enough', you always let him go. You don't jump on the guy who's lying; if he's lying and you can see he's had enough, you pull the others away from him. I've been in many fights, no one has ever broken the rules. Now my son fights. He is twentyone; he is a third-year student. He trains cage fighting, six to seven times a week, just to prepare for an ustawka. He doesn't want to be a professional fighter, he just trains for ustawki. After graduation he wants to make money by working in his profession. In our times it was different. We did sports; I trained race walking, five kilometres, another guy played rugby, there was judo. We were all more or less athletic, but today everyone trains something. It's a completely different situation. [Lechia Gdańsk_supporter]

Van Krieken analyses the concept of 'civilized barbarism' (2007: 31), which Elias developed in The Germans (1996). It concerns a situation where in spite of the development of state structures and the monopolization of violence by the state, a 'civilized' order sanctions 'barbaric' acts (the notable example is the extermination of Jews and Poles by the Nazis). This concept can also apply in the context of transformation of violence into another form, such as symbolic. If one believes in the stories about ustawki (the author of this study has never witnessed such a fight), they are not about the physical annihilation of the enemy at all costs, but about fighting and winning in the framework of certain rules. However, since such fights are illegal and involve immediate danger to life and health (there have been fatal incidents), many observers would interpret them as a kind of 'barbarism'. In addition, there is no external authority which would guarantee compliance with the principles and impose sanctions for breaking them. For example, the hooligan crew of Polonia Bytom admitted that their attack on the fans of Ruch Radzionków had been 'dishonourable' 
because the opponents were largely outnumbered and severely beaten. This 'dishonourable' act was to teach Ruch fans a lesson for their cooperation with the police 5 .

In a way, 'Team Tournament of MMA' provides a means of channeling hooligan energy in a legally acceptable formula. A similar idea appears in the book entitled Jestem kibolem (I'm a Hooligan, 2012). The author, Krzysztof Korsak (a fan of Stilon Gorzów), presents a fictional story featuring a group of fans and their 'adventures'. The book suggests the idea of legal, professionally organized fights between fans, which could be held at the stadiums before the matches: a game between two teams would be preceded by a fight between the two crews of their supporters. For now, however, it is only literary fiction, as it is hard to imagine such a form of 'civilizing' and commercialization of the hooligan craft.

The Ultras Division. At the same time, symbolic violence increasingly gains more importance, as evidenced in choreographies and performances. An aesthetic form provides fans of rival clubs with means to conduct their 'dialogue' with each other. This violence has a different dimension, it is verbal, one would say, discursive: by means of images and words, the opponents depreciate and humiliate each other. Importantly, creating aesthetic forms is also a form of competition. Polish fan periodicals and websites hold competitions for the best show of the month and the round (autumn and spring). Likewise, the Ultras World fan page on Facebook (which has a global impact) selects the best shows in the world each year. In 2016, Legia Warsaw was awarded the first place. The largest fan formations are proud to have their specialized groups of ultras, responsible for collecting material resources and preparing their presentations and performances. These groups are known by their own names, for example: 'Ultras Lechia', 'Nieznani sprawcy' (Unknown Perpetrators, Legia), 'Lech Poznań Ultras', etc.

The separation of ultras within the fan movement is proof of the 'division of function' (Elias 2009b: 32). The 'Calendar of the decade 2001-2010' published in the To My Kibice! ('It's Us the Fans!') magazine says: 'In 2002, ultras groups sprang up like mushrooms. (...) A division between ultras and hooligans was becoming more and more visible' ('Kalendarium dziesiecciolecia' 2011: 35). This division was not the case in the 1990s: 'The fan movement had this kind of attitude: there was no division between ultras and hooligans. You were a hooligan and an ultra at the same time. We never missed a chance for a scrap and everyone kept looking for an occasion to have one' (Miedź Legnica_supporter).

Until the mid-1990s, hooligan groups dominating in the Polish fan movement generally used only small, unimpressive flags in club colors. The run-down Polish stadiums were a scene of frequent fights and riots interrupting the matches. It was not until the second half of the 1990s that the supporters of the biggest clubs began to display large, hand-made flags and use pyrotechnic devices. The 1995/1996 season saw the first large crowd flags, featuring the club colors only, with no inscriptions. It is worth noting that the first attempts to introduce choreographies in the stadiums were made by supporters of the largest clubs with the largest turnout of committed fans. Fan performances included an increasing variety of elements (balloons, large flags on poles) and came to function as a plane of rivalry in terms of their content and form (scale). The 2001/2002 season marked a turning point when choreographies became an integral element of football matches. Initially, the rivalry focused mainly on the scale of the shows, measured by the number of fans taking part. While larger and better-organized groups tried to introduce more variety into their choreographies and make them more sophisticated, supporters of smaller clubs contented themselves with displays of the names and colors of their teams. The following seasons brought a radical change, as fan performances became not only spectacular shows, but also came to include a message to the outside world (Kossakowski et al. 2017).

Institutionalization of the Movement. The institutionalization of the movement in the form of officially registered supporters' associations, a trend which emerged in 2003, contributed to the development of ultras' performances ('Kalendarium. . ' 2011). The change was important considering that performances became increasingly more complex and complicated, which required close cooperation with club management in terms of logistics (installation, mounting, storage on club premises). Institutionalization of ultras groups also facilitated raising funds for choreographies, whose costs often exceeded tens of thousands złotys. Indirectly, the ultras introduced formal structure to the community of football supporters (There were also other reasons for the formation of associations: 'Everything began to get more organized, the tickets and other things; we could get the tickets only through the club, or through the association. And so associations were set up just to normalize all this stuff somehow' [Górnik Zabrze_supporter]). As a result, the fan movement went on to discover different areas of activity outside the stadiums and became a part of organized civil society. Since the activity of the ultras required a certain level of organization, logistics and budgeting, they played a major role in the process. Naturally, fan associations included not only the ultras, but also those responsible for charity actions, contacts with the club, etc.

The development of supporters' associations coincided with the development of self-government in Poland. In the period between 2003 and 2005 there were 4,000 new associations and 900 foundations established every year (Machowski 2010). It should be remembered that it was the period of Polish accession to the European Union (2004). Poland has become a country with democratic standards, which manifested itself in the lives of various social groups. On the other hand, the opening of borders resulted in a large emigration from Poland (estimated at the level of up to two million people), which affected the world of fans. A Górnik Konin (the Fourth League) 
supporter says: 'The town is depopulating at a high rate, the wave of emigration is rising. In addition, it has painfully affected our group' ('Działamy na własny rachunek' 2014: 39).

Established in 2007, the National Union of Supporters' Associations (Ogólnopolski Zwiazek Stowarzyszeń Kibicowskich, OZSK) intended to integrate fans in the struggle for their interests (and was institutional proof of their integration). Importantly, the integration of supporters' associations stemmed from the impact of external processes (changes in legislation, transformation of stadium infrastructure), deepening structural processes of state-building. Lawyers representing the National Union of Supporters' Associations were admitted to work with the parliamentary committee drafting the amendment to the Act on Mass Event Security in 2015. This made it possible to abolish mandatory fan ID cards with a photo, and reintroduce standing areas in stadiums at Polish league matches. However, the real impact of the OZSK on the football figuration should be considered modest. The reasons for this situation include the novelty of this form of social integration of fans, very strong antagonisms between fans and the 'established' entities (government, media and business), as well as fans' traditional dislike of more formal types of action.

Individual supporters' associations are much more vigorous and efficient. In the 2016/2017 season, fifteen out of the sixteen teams playing in the Polish Ekstraklasa (level 1) have their supporters' associations. Local groups of fans have also a representative in the management structure of the club, holding the position of Supporters' Liaison Officer (SLO). In most clubs, the position is held by a person from the fan community, which is another proof of the impact of modernization and civilizing factors. Clubs can cooperate more easily with their fans when they are represented by an institutionalized association. The activity of associations facilitates a number of issues and, above all, enables their expansion in other spheres. The conflict with the authorities, the need for self-organization and the ensuing reflection on their own place in the field of football made the fans aware of possibilities for expanding their activity to other areas. The case of the Lech Poznań Supporters' Association (Stowarzyszenie Kibiców Lecha Poznań, SKLP) is an example of the 'functional differentiation' of the fan movement in the mid-2010s.

Founded on 1 April 2014, the SKLP is a continuation of the organization called Wiara Lecha ('Lech Boys'), which was not dissolved, but changed its formula and became a sports association. Wiara Lecha is now a football team made up of Lech Poznań supporters, a sports section for fans who would like to prove themselves on the pitch. The team plays at the sixth level of competition and its games provide supporters of Lech with an opportunity to display more 'spontaneous' support, including also the use of pyrotechnics. One of the fans describes their atmosphere as follows: 'The atmosphere and the match time were perfect. Beautiful weather, cold beer and lots of pyrotechnics, which is all you need to enjoy such a relaxing game' (TPS Winogrady. . 2015: 37).

According to information provided on its website, the SKLP defines its mission quite broadly: integration of the terraces, organization of fan activity (including trips to matches, choreography, cheering, fan clubs and thematic sections), cooperation with the club (tickets, marketing campaigns, organization of matches, joint actions), organization of charitable and patriotic actions, representing supporters in relations with the media and the authorities. The association has groups of football fans practicing various sports: cycling ('Fans' Cycling Section'), martial arts (WL Fight Club, only for active supporters of the club), football (Wiara Lecha), and running.

The SKLP report for 2015 lists a number of different forms of its activity. Throughout the year, there were nineteen match performances and twenty-five trips to away matches (the league and the cup, 37,362 fans in total). As part of its charity activity, the SKLP held three collections of gifts for Poles living in the former eastern borderlands; there were also two fairs for children. The association joined in the celebrations of the 97th anniversary of the Wielkopolska Uprising (1918-1919) (financial contribution and participation in the event, the fans fired flares). A collection of funds for ultras' purposes held on the Internet and during matches raised PLN 200,000 PLN (in the case of large-size choreographies, the costs of their preparation can amount even to tens of thousands złotys). The above list does not mention the hooligan aspect (e.g., the number of fights), although it is widely known that Lech Poznan supporters have their own 'crew'. Officially, the association cannot support hooligans, but it is certainly aware of their existence. If all these types of activity (including the hooligan) are considered under the umbrella of football fandom in a particular city, the case of Poznań demonstrates 'functional differentiation' on a large scale. The initiatives of the SKLP go beyond the sphere of fandom proper and integrate people from different circles.

It needs to be stressed that the civic and social development of supporters' associations reflects a broader context, in which a number of different organizations create their particular identity policies in contemporary Poland. This would seem to confirm that the fan movement is developing into a figuration capable of reaching particular aims and objectives in a modern and official way. The multidimensional sphere of fan activism reflects the fact that

In the course of the growing differentiation and integration of social functions and increasing democratization and equalization, the people involved have forced themselves and each other to behave with greater consideration; consideration of the feeling and interests of more people, for more of the time. (...) The level of their mutually expected self-restraint has risen. (Wouters 1986:11)

'The broadening of the figurative field' of fandom beyond typical 'cheering' actions stems from several 
motivations, and the respondents indicate such factors as: the intention to demonstrate the positive side of fan activity, to break the stereotype of the 'hooligan' and 'thug', to use the energy and potential of the group, to work for the sake of the Club, to raise the new generations of fans, to strengthen ties in local communities, to create attitudes and values and, in a broader sense- to serve others (as the supporter of GKS Tychy summed up: 'We just want to help'). The aspects of social activity of fan movement include such dimensions as: charitable activity (collecting food supplies and everyday items for foster care institutions, nursing homes, animal shelters; organizing Christmas parties; donating blood); social and educational activity (organizing sports tournaments, camps and fairs for children); commemorative and political activity (participating in events celebrating local and national holidays); production, management and making profit from fan culture (fan brands, merchandise, fan shops); communication and publishing activity (magazines, websites).

\section{Social Conflict and Identity Politics}

One of the most important dates marking a change of the football 'figuration' in Poland was 18 April 2007, when Poland was selected (together with Ukraine) as a cohost of Euro 2012. Modernizing stadiums and highways, the Polish government decided to 'modernize' also supporters, mainly by ousting football hooligans from the game (Antonowicz, Grodecki 2016). The 2009 amendment of the Act on Mass Event Security was to serve the purpose. As a result, there was a significant increase in the number of arrests for football-related offenses. Before Euro 2012, fans vigorously protested against the policy of the government by presenting choreographies with political contents (e.g., 'Donald [Tusk, the Prime Minister at the time, RK] you moron, football hooligans are going to bring your government down'), and organizing street happenings. Fans started to boycott some media supporting the strategy of the government (the Gazeta Wyborcza newspaper, TVN television company). It was quite apparent that in this period the pressure from the state (considered as a monopolist in terms of using violence) had a strong influence on the behavior, actions and structure of fandom. Restrictive law and its strict enforcement practically pushed out violence from the stadiums (although hooliganism as such did not vanish). Fans were forced to 'correct' their behavior and to reformulate their identity. The process of change can be attributed to two factors: the pressure from the system and self-reflection.

A comment from a Widzew Łódz fan aptly sums up: 'fans should thank Prime Minister Tusk for choosing this particular group as a scapegoat to improve his ratings in the polls just before the elections. This provided a great opportunity to unite and build a real social group which has its own representatives, its own demands, values and a common enemy' (Małecki 2014: 11). Donald Tusk, the Polish Prime Minister (2007-2014), stated: 'Even if the struggle for peace and security for people in the stadiums is going to take weeks or months, as of today we will not step back an inch' 6 . This antagonism consolidated the line of division and contributed to the strengthening of fans' collective identity. Indeed, a typical feature of contemporary conflicts is that they are accompanied by practices constructing and consolidating social identity (Kriesberg \& Dayton 2012).

Lewis Coser observes that "conflict with other groups contributes to the establishment and reaffirmation of the identity of the group and maintains its boundaries against the surrounding social world' (1964: 38). The experience of the conflict was instrumental in expanding the activity of the fans and, as it turned out, their organizational skills manifested during the protests were to be used in other fields. Max Weber (1978) suggests that new rules are created as a result of changes in the external conditions of life, but it is new actions that are always decisive. Indeed, protests, marches, petitions, performances became a driving force of their reflexivity, the source of new solutions with which fans could expand their figuration.

The integration of the movement is reinforced by its strong ideological commitment. Ideological trajectories are determined by the conservative-patriotic attitude with a strong appeal to religious (Roman Catholic) or military symbolism. Since in Poland there are no (official) supporters of leftist provenance, there are no such symbols as the image of Che Guevara, the red star or the hammer and sickle (as is the case in Livorno, see Doidge 2013). In the Polish context, antisystem, rebellious slogans are expressed by means of conservative or right-wing performances. Here, the explanation lies in the recent history of communist rule in Poland until 1989, which for many years has 'blocked' the use of metaphors of 'class struggle' in the identity politics of supporters. Fans are increasingly more often involved in the promotion of their attitudes on various occasions; for example, they take an active part in the national Independence March, celebrations of the anniversary of the Warsaw Uprising, or local festivals. This arouses 'external' conflicts and tensions with groups which are not related to the field of football and hold different (e.g., leftist views). As a result, the fan figuration is shaped by new connections and interactions. Relations with other figurations make the social process of supporting different than it used to be in the days when a group of sports fans focused on football events or 'internal' matters, such as clashes with rivals from other fan groups.

\section{Conclusions: The 'Dark Side' and the Future of the Social Process}

Apart from the above mentioned activity incorporating fans in a broader-civic - context, what cannot remain overlooked is controversial, often 'uncivilized' and illegal dimensions: hooligan activity and vandalism; political extremism (displaying illegal political symbols, e.g., associated with racism); criminal activity (engaging in drug trafficking, robberies, organized crime). 
As mentioned above, Polish hooligan groups employ a specific code of conduct, do not (usually) interfere with the general public, and are mainly composed of members involved in martial arts. These features have been discussed as evidence of a peculiar 'civilization' of this domain. Why are then hooligan fights pointed out as 'uncivilized' activity? The answer is: because they are illegal and they may result in the loss of life or health, which makes them not only unacceptable, but also 'barbaric' from the moral and social perspective. Their 'modernization', 'professionalization' and 'civilization' concerns the interior of the fan world, guided by a particular code of values and attitudes. In the case of political views, it is considered that if fans articulate them and organize themselves around them, this could be assessed as civic behavior (constitutional freedom to express political views). It is a matter of 'identity politics', regardless of whether it refers to left- or rightwing attitudes. Only when these views are moving into illegal areas (fascist, racist symbols), should they be condemned. In the case of criminal groups, it concerns fans going over to the 'dark side', for example becoming included in the structure of these groups. In the case of criminal groups, it concerns fans going over to the 'dark side', for example becoming included in the structure of these groups ${ }^{7}$.

While it is certainly necessary to note the coexistence of positive initiatives with the 'dark side' of fandom, it seems that the development of new, legal, and culturally and socially acceptable forms of activity is the symptom of the civilizing nature of the fan figuration (or a large part of it). Again, Elias's metaphors can prove useful in the analysis: the relationship of interdependence between state-formation processes, modernization and Europeanization of Polish football (Euro 2012, modern stadiums, professional league), and the maturity of a part of the fan movement made it possible to implement a broad sphere of civic cooperation within fandom. It is definitely the result of a historical process that was neither planned nor directed. For this reason, the development of fan culture needs further analysis, especially in the context of constantly changing 'external' circumstances.

\section{Notes}

1. 'Planning' is an inherent feature of the communist system: 'In the communist countries, the view of history as a structured change of society in a specific direction remains alive. But with it, there survives at the same time the idea that this change is leading inevitably to the realization of communist ideals' (Elias 2009b: 18). Sport was one of the most important elements of propaganda discourse, as it served as 'proof' of the superiority of the ideals of communism over capitalism. Fans and their 'rebellious' behavior tried to break down this discourse.

2. In 1990, the unemployment rate was at $6.6 \%$, and reached $14.9 \%$ in 1995; in 1991, the gross domestic product fell to $80 \%$ of that recorded in 1989, and returned to this level only in 1996 (GUS 2014). The most dramatic situation was in the cities where a previously strong, state-owned industrial company was not able to meet the demands of free-market reality. The collapse of such companies often meant a degeneration of urban centers, whose residents had to look for jobs in other parts of the country (or, after 2004, abroad).

3. A supporter of Victoria Jaworzno recalls the local skinhead group as follows: 'In this group there were ideological national socialists, who showed their sympathies during matches by waving flags with a skull, shouting "SS SA Victoria", displaying the symbols of the KKK [Ku Klux Klan, RK] (. . . ). The beating of a black player of Garbarnia [a club from Cracow, RK], which received wide coverage in the media, was associated with Victoria skinhead fans' (Szymon.Victoria Jaworzno 2014: 44).

4. The code is available at: http://kibicowskiezycie. pl/325,KODEKS_KIBICA. Retrieved April 04, 2017. The rules include: supporting fans in the fight against the police (even if it concerns hostile fans); ban on the use of dangerous objects in the fights; ban on mistreatment of defeated opponents, including robbery. These principles do not form an ultimate list, and many comments on internet forums indicate that in some cases the rules are not obeyed. However, such supra-local, nationwide ways of regulating behavior resemble monopolization, which accompanied e.g., the formation of larger social entities and states. Elias described it as a type of 'formalization' (1996). Not sanctioned by any 'coercive apparatus' (as in the case of the state), the fan code works on the principle of ostracization: 'dishonourable' and unfair behavior violating the spirit of the rules is stigmatized by means of rumours and symbolic violence.

5. Information from the To My Kibice magazine, no 1/2014. It is worth mentioning that in the fan circles, cooperation with the police is considered the most 'shameful'. This attitude probably goes back to the communist era, when people informing on friends or involved in cooperation with authorities were ostracized. An older fan from Gdańsk recalls: 'There were those who began to work with the ZOMO [the Motorized Reserves of the Citizens' Militia in communist Poland, RK] or the militia. They had no return. No one would shake hands with them. Yesterday they were buddies, the next day they knew they had no business here at all'.

6. http://namonciaku.pl/3miasto/1,113052,9551974,Jak_ Donald_Tusk_z_kibicami_w_Bydgoszczy_wojowal.html. Retrieved March 03, 2017.

7. There is no clear data indicating the scale of the phenomenon. From time to time, the media carry information about arrests of several people associated with fan circles and involved in criminal activity (e.g., Zawisza Bydgoszcz: seven people; Cracovia: nine). The police recognized the Legia Warsaw hooligan crew (called 'Teddy Boys 95') as an 'organized criminal group' (see: http://www.tvp.info/7519974/bojowka-legii-uznana-za-gang. Retrived March 03, 2017.

\section{Acknowledgments}

Research for this project was made possible by a grant funded by the Polish National Centre of Science (no. 2013/09/D/ HS/6/00238). 


\section{References}

Antonowicz, D., \& Grodecki, M. (2016). Missing the goal: Policy evolution towards football-related violence in Poland (1989-2012). International Review for the Sociology of Sport. doi:10.1177/1012690216662011

Artur. (2002). Kibic też człowiek. To My Kibice, 2, 19.

Bauman, Z. (1990). Thinking Sociologically. Oxford: Blackwell.

Coser, L. (1964). Functions of Social Conflict. New York: The Free Press.

Doidge, M. (2013). The Birthplace of Italian Communism: Political Identity and Action Amongst Livorno Fans. Soccer and Society, 14(2), 246-261. doi:10.1080/14660 970.2013.776471

Dubai, S. (2010). The neoliberalization of football: Rethinking neoliberalism through the commercialization of the beautiful game. International Review for the Sociology of Sport, 45(2), 123-146. doi:10.1177/1012690210362426

Działamy na własny rachunek. (2014). To My Kibice, 1, 36-39.

Elias, N., \& Dunning, E. (1986). Quest for Excitement: Sport and Leisure in the Civilizing Process. Oxford: Blackwell.

Elias, N. (1978). What is sociology? London: Hutchinson.

Elias, N. (1987). Involvement and Detachment. Oxford: Blackwell.

Elias, N. (1996). The Germans: Power Struggles and the Development of Habitus in the Nineteenth and Twentieth Centuries. New York: Columbia University Press.

Elias, N. (2009a). Social Processes. In N. Elias (Ed.), Essays III. On Sociology and the Humanities (pp. 4-8). Dublin: University College Dublin Press.

Elias, N. (2009b). Towards a theory of social processes. In N. Elias (Ed.), Essays III. On Sociology and the Humanities (pp. 9-39). Dublin: University College Dublin Press.

Elias, N. (2009c). Football in the process of civilization. In N. Elias (Ed.), Essays III. On Sociology and the Humanities (pp. 190-197). Dublin: University College Dublin Press.

Elias, N. (2012). On the Process of Civilisation: Sociogenetic and Psychogenetic Investigations. Dublin: University College Dublin Press.

Er, A. (2014). Z pamiętnika Galernika. Magia lat 90-tych. Łódź: SPRINT STUDIO.

Er, A. (2015). (Vol. 2. Z pamiętnika Galernika. Magia lat 90-tych. Łódź: SPRINT STUDIO.

Fitzpatrick, C. (2013). The struggle for grassroots involvement in football club governance: experiences of a supporteractivist. Soccer \& Society, 14(2), 201-214. doi:10.1080/1 4660970.2013.776468

Gibbons, T. (2014). English national identity and football fan culture, who are ya? Surrey: Ashgate University Press.

Giulianotti, R. (2011). Sport Mega Events, Urban Football Carnivals and Securitised Commodification: The Case of the English Premier League. Urban Studies (Edinburgh, Scotland), 48(15), 3293-3310. doi:10.1177/ 0042098011422395

Gorący, A. (2009). Widowisko sportowe - studium agresji. Uwarunkowania zachowań agresywnych kibiców piłki nożnej. Pruszków: WSKFiT.

Goksiński, J. (2014). Klubowa polska piłka nożna. Lata 70. Warszawa: PZI Softena.
Guschwan, M. (2007). Riot in the Curve: Soccer Fans in Twenty-First Century Italy. Soccer \& Society 8(2-3), 250-266. doi.10.1080/14660970701224467

Kalendarium dziesięciolecia. (2011). To My Kibice, 2, 32-51.

King, A. (1998). The End of the Terraces. Leicester: University Press.

Korsak, K. (2012). Jestem kibolem. Brzezia Łąka: Poligraf.

Kossakowski, R. (2015). Where are the hooligans? Dimensions of football fandom in Poland. International Review for the Sociology of Sport. doi:10.1177/ 1012690215612458

Kossakowski, R., Szlendak, T., \& Antonowicz, D. (2017). Polish Ultras in the Post-Socialist Transformation. Sport in Society. doi:10.1080/17430437.2017.1300387

Kriesberg, L., \& Dayton, B.W. (2012). Constructive Conflicts: From Escalation to Resolution, Lanham, Maryland: Rowman \& Littlefield.

Layder, D. (1986). Social Reality as Figuration: A Critique of Elias's Conception of Sociological Analysis. Sociology, 20(3), 367-386. doi:10.1177/0038038586020003006

Machowski, T. (2010). Rozwój społeczeństwa obywatelskiego w Polsce. Opis dobrych praktyk. Kraków: FRDL.

Malcolm, D. (2012). Sport and Sociology. London, New York: Routledge.

Malkontent. (2002). Solówki - wyjście idealne? To My Kibice, 2, 11.

Małecki,A. (2014). Kibice, a polityka. Myśl.pl. Pismo społecznopolityczne, 1, 9-11.

May, A. (2015). An ,anti-sectarian” Act? Examining the importance of national identity to the "Offensive Behaviour at Football and Threatening Communications (Scotland) Act". Sociological Research Online, 20(2), Retrieved from http://www.socresonline.org.uk/20/2/14. html. doi: $10.5153 /$ sro.3649

Mennell, S., \& Goudsblom, J. (1998). Introduction. In N. Elias (Ed.), On Civilization, Power, and Knowledge. Selected Writings (pp. 1-48). Chicago, London: The University of Chicago Press.

Mennell, S. (1996). Civilizing and Decivilizing Process. In J. Goudsblom, D.M. Jones, \& S. Mennell (Eds.), The Course of Human History. Economic Growth, Social Process and Civilization (pp. 101-116). Abingdon, New York: Routledge.

Mennell, S. (2007). The American Civilizing Process. Cambridge: Polity Press.

Nowak, S. (1981). Values and Attitudes of Polish People. Scientific American, 245(1), 45-53. doi:10.1038/scientificamerican0781-45

Numerato, D. (2015). Who Says 'No to modern football'?: Italian Supporters, Reflexivity, and Neo-liberalism. Journal of Sport and Social Issues, 39(2), 120-138. doi:10.1177/0193723514530566

Pearson, G. (2015). Ethnography and the Study of Football Fan Cultures. In A. Schwell, N. Szogs, M. Kowalska, \& M. Buchowski (Eds.), New Ethnographies of Football in Europe. People, Passions, Politics (pp. ii-xx). Basingstoke: Palgrave MacMillan.

Tarkowski, J. (1994). Wtadza i spoteczeństwo w systemie autorytarnym. Warszawa: ISP PAN. 
Tischner, J. (1992). Etyka solidarności i Homo sovieticus. Kraków: Znak.

TPS Winogrady Poznań - Wiara Lecha Poznań. (2015). To My Kibice, 10, 37.

Wąsowicz, J. (2006). Biało-zielona „Solidarnośc”. O fenomenie politycznym kibiców gdańskiej Lechii 1981-1989. Gdańsk: Finna.

Weber, M. (1978). Economy and Society: An Outline of Interpretive Sociology. Berkeley: University of California Press.
Webber, D. M. (2015). 'Playing on the break': Karl Polanyi and the double-movement 'Against Modern Football'. International Review for the Sociology of Sport, doi: 1012690215621025.

Wouters, C. (1986). Formalization and informalization: changing tension balances in civilizing processes. Theory, Culture \& Society, 3(2), 1-18. doi:10.1177/0263276486003002002 'Zgred'. (2002). Okiem zgreda. To My Kibice, 3, 31. 